\title{
0 outro lado do Império: as disputas mercantis e os conflitos de jurisdição no Império Luso-Brasileiro
}

\section{The other side of the Empire: commercial disputes and jurisdictional conflicts in the Luso-Brazilian Empire}

\section{Cláudia Maria das Graças Chaves}

\section{Os espaços e poderes imperiais}

O período marcado pela transferência da Corte Portuguesa para a América e pela conseqüente constituição do Reino do Brasil tem sido revisitado freqüentemente pela historiografia brasileira. Uma das temáticas mais pertinentes para essas releituras tem sido a busca da construção dos conceitos de nação naquele período, tanto no sentido da transição para a formação da nação moderna, quanto no sentido da persistência e da permanência dos traços característicos de sociedades e estados do Antigo Regime. O objetivo é, evidentemente, investigar o que isso significava para o Brasil, que logo se constituiria em um Estado independente.

François-Xavier Guerra tem-nos auxiliado a repensar a América Ibérica dentro deste contexto de transformaçôes entre fins do século XVIII e início do XIX. Para o autor, a "nação" do Antigo Regime era definida em um âmbito muito geral de províncias, países ou reinos. Nesta perspectiva, a Espanha era uma monarquia que compreendia todos os povos por ela governados, sendo que isso definiria uma Nação. As afiliações extraterritoriais entre vassalos ${ }^{1}$ da mesma monarquia geraram o sentimento de unidade e pertencimento necessários para a identificação nacional, assim como o do sentimento de patriotismo, que o autor definiu como "patriotismo imperial". 
Esse sentimento de unidade, comum à monarquia portuguesa e ao seu império, tomou caminhos diferenciados para os domínios ibéricos no início do século XIX. Enquanto a Espanha, a partir do bloqueio continental e da invasão francesa, passava a identificar a nação ao Estado espanhol, fracionando os laços do "patriotismo imperial", em Portugal a situação era bem diferente em função da transferência da Corte para o Brasil e do fortalecimento do Império Luso-Brasileiro. As circunstâncias que transformam a Monarquia hispânica não são tão simples quanto descrevemos, mas podem ser sinteticamente apresentadas através das palavras de Xavier Guerra:

A unanimidade de um "patriotismo" comum a ambos os continentes serve para postular a existência da "nação", mesmo que este "patriotismo" não tivesse, no início, caráter muito moderno, pois se tratava da defesa do rei, da religião, de valores e costumes comuns. No entanto, logo surgirão os problemas, quando for necessário dar expressão política à unidade moral. As cortes de Cádis, seguindo o exemplo francês e a forte corrente unificadora do século XVIII, definiram-na como nação unitária. Na Espanha peninsular, tal definição não provocou, de momento, grande problema. A "nação" Espanha (...) foi socializada na luta contra o invasor. (...). Na América, o imaginário unitário da nação provocou imediatamente incontáveis problemas. Os governos e os constituintes peninsulares foram incapazes de superar seu imaginário unitário de nação e sua visão "colonial" da monarquia. A recusa da igualdade política total entre os dois continentes e a incapacidade de inventar uma estrutura política plural - de governo e de representação - acabaram provocando o surgimento de países independentes na América (GUERRA, 2003:57-8).

No Caso de Portugal e de seu vasto império, temos situações semelhantes aos modos de governo e às afiliações extraterritoriais dos vassalos da monarquia, embora existissem distinções entre as formas de participação política das periferias em relação ao centro dentro dos impérios ibéricos. António Manuel Hespanha (1994) trouxe uma grande contribuição para compreendermos melhor um novo conceito de monarquia portuguesa, bem como das concepções de nação vinculadas a um ideário e a posturas políticas próprias de uma sociedade de Antigo Regime. Para o autor, essa monarquia se caracterizou, pelo menos até meados do século XVIII, por sua forma corporativista. Isso implicava em redimensionar a 
relação do todo com suas partes, isto é, do centro com sua periferia e viceversa: o poder político negociado nas diversas hierarquias; a limitação jurídica do poder legislativo da Coroa; a prevalência das relaçôes de compromisso e dependências pessoais que formavam verdadeiras redes de favores; e uma certa autonomia aos poderes locais, mesmo que contrastando com as disposiçóes reais. O conjunto de características desses laços imperiais extrapolou, sem dúvida, os meados do século XVIII e, de certa forma, elas foram até mesmo realçadas com as políticas reformistas que, embora tentassem racionalizar a administração monárquica, mantinham fiéis os laços de compromissos e de submissão dos interesses públicos aos interesses privados. No final do século XVIII e início do século XIX, a monarquia portuguesa com seus domínios estava ainda muito distante da constituição de sociedades e estados constitucionais modernos e soberanos. O reformismo ilustrado e a influência do pensamento liberal não foram suficientes para dissipar as características corporativistas e hierárquicas prevalentes.

Neste sentido, os projetos políticos, bastante plurais, no que dizia respeito ao centro e periferias do império português, ganhavam contornos mais específicos para o fortalecimento dos laços entre o centro europeu e a América. Uma das características mais marcantes dos projetos reformistas ilustrados, levados a cabo por seu principal arquiteto, D. Rodrigo de Sousa Coutinho, era a de se ampliar os conhecimentos sobre o território americano - população, produção, comércio, cartografia, caminhos etc e propor ações de intervenção a partir de princípios fisiocráticos e liberais.

A transferência da Corte em 1808, o Tratado de Comércio com a Inglaterra em 1810 e a elevação do Brasil à categoria de Reino em 1815 reforçaram os projetos reformistas destinados ao Brasil. A transposição do centro de decisão de poder da monarquia para uma área periférica, isto é, o deslocamento do centro em direção à periferia, embora tenha fortalecido o sentido do Império Luso-Brasileiro, embaralhou as já complexas relações entre os vassalos de distintos territórios em relação à Coroa Portuguesa, principalmente se pensarmos nos distintos projetos destinados aos dois lados do Atlântico.

A solução de Portugal para o bloqueio peninsular ibérico como a "opção americana"2, isto é, a manutenção do domínio europeu na Améri- 
ca dentro dela, foi inicialmente bem sucedida e obteve apoio de outras potências européias, entretanto, os desdobramentos da transferência do centro de poder acabaram por revelar as profundas assimetrias entre as partes da monarquia. A mudança da posição geográfica do centro provocou mais reações do que se poderia supor as afiliações de vassalagem extraterritoriais. Neste sentido, o modelo de monarquia portuguesa definida por Hespanha (1994) tenha sido melhor empregada ao contexto do século XVIII. A nova situação da monarquia, ao início do século XIX, fragilizava o anterior equilíbrio imperial. Enquanto os peninsulares expressavam um sentimento de perda, sobretudo nos assuntos mercantis, os americanos apostavam numa igualdade de direito e de fato. Isso implicaria adoção das formas corporativas de poder entre as elites americanas e não distinção entre os usos e costumes do novo mundo em relação ao velho continente.

\section{A Junta de Comércio na América portuguesa: definição de novos poderes}

A situação descrita acima pode ser analisada a partir da reordenação de poderes das elites mercantis e mercadores luso-brasileiros em torno da Junta de Comércio. A Junta, criada em Portugal durante o reinado de D. José em 1755, em substituição à Confraria do Espírito Santo, foi reformulada em 1788 passando a ser designada Junta de Comércio, Agricultura, Fábricas e Navegação deste Reino e seus Domínios - JCAFN - e passa a ter ampliado seu poder como fórum de decisões nas questôes comerciais dentro da monarquia portuguesa. A ela se subordinou a Mesa do Bem Comum dos Mercadores de retalho - cujos estatutos foram criados em 1757 para o estabelecimento de suas classes privilegiadas. Dominada pela elite mercantil portuguesa, a Junta tinha amplo poder não somente sobre as questôes comerciais, mas também sobre a produção agrícola e industrial. Sua ênfase em uma política protecionista chocava-se com os discursos mais liberais de certos grupos políticos que defendiam uma maior liberalização de mercados e extinção de alguns monopólios régios. Estas discordâncias eram bem absorvidas pela Junta, conquanto ela representasse os interesses corporativos da elite econômica portuguesa. Entretanto, o 
mesmo não aconteceu a partir da transferência da Corte e de suas Instituiçôes para a América.

No Brasil, a Junta de Comércio, Agricultura, Fábricas de Navegação foi criada em 23 de agosto de 1808. Como, desde 1788, a Junta era incluída na categoria de tribunal, na América, ela passou a receber também as atribuições da então extinta Mesa de Inspeção - esta possuía funções fiscais e técnicas relativas ao controle do açúcar e do tabaco. A Junta era responsável por matrículas de comerciantes, falências comerciais, aulas de comércio, além de dar pareceres a consultas dirigidas ao Órgão e relativas às áreas de atuação abrangidas, ou seja, ao comércio, à navegação, à agricultura e às fábricas.

A Junta de Comércio, mesmo tendo sido elevada à condição de tribunal, continuava a ser um órgão mais consultivo e menos deliberativo, visto que ela emitia um parecer final, através de seu Juiz Conservador, para que o Rei tomasse a decisão. Não podemos deixar de lembrar que essa transformação ocorre como desdobramento das ações pombalinas de hierarquização e distinção social dos Homens de Negócio, que, por força da lei, se destacavam no quadro social mercantil dos demais membros do corpo mercantil. Isso explica o fato de a Junta de Comércio não ter se tornado uma instituição menos burocrática com poder de tribunal decisório de última instância como propunha Domingos Vandelli ${ }^{3}$. Para Nuno Madureira, o sinal da elevação da Junta à categoria de tribunal é dado pela presença de um titular da Nobreza na Presidência, o Visconde de Vila Nova de Cerqueira, bem como as mudanças nos procedimentos formais, isto é, os deputados, que até então iam para as conferências com seus fatos habituais, passavam a se apresentar de toga e carruagem ${ }^{4}$. Essa nova organização da Junta certamente alterava o equilíbrio de composição entre "homens de negócio" e magistrados, o que levou o Secretário da nova Junta em Portugal, Teotônio Gomes de Carvalho, a afirmar: "jamais os homens de negócio podem ser Ministros próprios do tribunal” por não poderem arbitrar sobre interesses particulares ${ }^{5}$. Para Jorge Pedreira, a criação da Junta de Comércio, em 1755, constituiu-se em um momento crucial para a distinção dos "homens de negócio" de grosso trato em relação ao comércio de varejo. Ela não inaugurou a distinção social, já pré-existente, mas foi a sua primeira expressão institucional como "instrumento de intervenção do poder na classificação dos agrupamentos e dos agentes so- 
ciais na esfera comercial"'. Dessa função institucional e de distinção social derivava a honorificação da atividade dos "homens de negócio" através da concessão de privilégios e títulos.

No Brasil, a composição da Junta não era diferente de Portugal, os cargos eram ocupados por nobres, magistrados e negociantes. Ela foi inicialmente presidida pelo Conde de Aguiar e teve como seus membros: Luiz José de Carvalho e Mello - Desembargador do Paço -, Leonardo Pinheiro de Vasconcelos - Conselheiro da Fazenda -, Manuel Moreira de Figueiredo - Desembargador da Casa de Suplicação -, Caetano Gomes, Mariano José Pereira de Fonseca, João Rodrigues Pereira de Almeida, Elias Antônio Lopes, Antônio da Silva Lisboa e, finalmente, José da Silva Lisboa, o Visconde de Cairu. ${ }^{7}$ Sua constituição na América representou o início do processo de institucionalização e da profissionalização comercial no Brasil, através das aulas de comércio, destinadas a instruir comerciantes sobre técnicas contábeis e legislações comerciais. A Junta teve um papel decisivo na formulação e na execução de reformas econômicas liberais e para a consolidação do espaço de novos saberes mercantis; foi também o primeiro canal importante de representação política de grupos mercantis no Brasil.

Nos termos do Alvará que criou a Instituição no Brasil podemos ler:

Eu, o Príncipe Regente faço saber aos que o presente alvará com força de Lei virem (...) E sendo de esperar que da criação de um tribunal semelhante ao de Portugal que entenda e providencie em todos os objetos dessa natureza, resultem grandes utilidades em benefício comum aos meus fiéis vassalos habitantes deste vasto e feliz continente (...). Determinei que fossem livre o erigirem-se fábricas de qualquer gênero e qualidade e que estabeleci a ampla liberdade de comércio. (...). Haverá nesta Corte um tribunal, que sou servido criar que se denominará Junta de Comércio, Agricultura, Fábricas e Navegação Deste Estado e Domínios Ultramarinos. (grifos meus) ${ }^{8}$

Como é possível notar, a Junta criada no Brasil passou a funcionar paralelamente à Junta existente em Portugal. No corpo do Alvará ainda podemos ler que a instituição que se criava no novo continente deveria ser regida pelas mesmas leis e estatutos que haviam criado, em 1788, a nova configuração da Junta de Portugal. As diferenças, nos termos da criação, estão na ênfase do comércio livre e da liberdade de criação de todo tipo de fábricas na América; e na denominação, isto é, enquanto em Portugal a Junta é definida por "deste reino e seus domínios", no Brasil foi definida 
como "deste estado e seus domínios ultramarinos". Estas diferenças, como veremos a seguir, causaram muitas polêmicas e nos fazem atentar para os problemas mencionados acima sobre as relaçóes assimétricas de poder dentro da monarquia portuguesa, mesmo com a transferência da Corte para a América e a posterior transformação da antiga colônia em Reino Unido a Portugal e Algarves.

Embora tivesse o papel de arbitrar os problemas comuns ao Império Luso-Brasileiro, o fato de ter sido estabelecida na Corte do Rio de Janeiro causou, desde o primeiro momento, conflitos de interesses entre as elites mercantis brasileiras e as elites mercantis portuguesas. $\mathrm{O}$ principal ponto de discórdia foi o reforço do discurso liberal para o mercado do Brasil, simultaneamente à permanência de privilégios estabelecidos para os mercados de Portugal. Para os americanos, a maior proximidade das relaçóes entre Brasil e Portugal poderia significar os mesmos benefícios da estrutura corporativa e privilegiada das cinco classes de mercadores, além das possibilidades de riqueza e enobrecimento existentes em Portugal. Fazer parte do Império ou pertencer ao Reino Unido de Portugal e Brasil significaria não haver distinçôes para os súditos em ambos os lados do Atlântico, entretanto, não era bem isso que propunha o projeto reformista e nem era a intenção da Junta de Comércio transpor para o Brasil a mesma estrutura administrativa e corporativista existente em Portugal, mesmo porque isso implicaria romper com a estrutura de privilégios dos negociantes portugueses no Brasil, o que, de fato, acaba por acontecer, mas não em função dos interesses mercantis brasileiros, mas, sim, em função da abertura comercial de 1808 e do Tratado de Comércio e Amizade estabelecido com a Inglaterra em 1810.

Como exemplo deste conflito, podemos acompanhar, dos dois lados do Atlântico, a disputa pela direção dos parâmetros e das condutas de mercado dentro do Império. Este é o caso das decisões sobre o comércio ambulante: na América, a decisão sobre liberar o comércio ambulante irritou os comerciantes varejistas brasileiros, os quais gostariam de ver, aqui, adotadas as cinco classes privilegiadas de mercadores com suas prerrogativas de arruamento e aposentadorias das Lojas'; em Portugal, os comerciantes se irritavam pelo fato de as novidades "brasileiras" chegarem até eles, isto é, a introdução de comércio ambulante, sem que se fossem respeitados os privilégios estabelecidos por seus estatutos. 
O Alvará de 27 de março de 1810 causou a grande polêmica entre os comerciantes varejistas dos dois lados do Atlântico. Ele foi elaborado como resultado de consulta à Real Junta de Comércio, Agricultura, Fábricas e Navegação do Estado do Brasil e Domínios Ultramarinos. Determinava o Alvará:

Ficará virtualmente derrogada a anterior legislação, que proibia nas cidades e vilas, a venda das fazendas pelas ruas e casas, mostrando a experiência que foi sempre impraticável a exata observância daquela pragmática suntuária, que os verdadeiros princípios de economia política desaprovam, e que ainda com as modificações do sobredito Alvará [de 21 de abril de 1751], e não obstante a proibição, prevaleceu em todos os tempos a franqueza de tais vendas, que $o$ arruamento dos mercadores nas grandes cidades fez necessárias; exigindo o interesse geral que seja livre a todos os meus fiéis vassalos procurar na útil divisão de trabalho, conforme a propensão e escolha de cada um, os meios de sua subsistência, além de concorrer a multiplicidade das compras e vendas para a extensão do mercado e facilidade de sua extração (...), com proporcional acréscimo na coleta das minhas rendas (...) que tanto convém promover, assim como sustentar com justo equilíbrio pela concorrência de maior número de distribuidores os ganhos que podem produzir as vendas a retalho sem gravame do bem público, ao qual se não deve antepor o interesse particular de corporação alguma. (...) tendo eles [mercadores com lojas] a seu favor pela vantagem da situação, e menor despesa nos transportes das fazendas, a certeza da sua pronta extração, e consumo das pessoas ricas, que naturalmente procuram suprir-se nas grandes lojas, onde tem a oportunidade da escolha em mais crescido número de artigos: sou servido (...) derrogar o Alvará de 21 de abril de 1751 para que fique livre a todos os meus fiéis vassalos vender, como atualmente praticam, pelas ruas e casas todas as mercadorias, de que se tenham pago os competentes direitos. (...)"10 (grifos meus).

Como dissemos acima, este Alvará causará uma grande polêmica entre os varejistas no Brasil, pois a idéia do estabelecimento sem riscos e o privilégio de vender mercadorias pré-estabelecidas evitava a concorrência tanto entre lojistas, quanto entre lojistas e mercadores ambulantes. Tudo isso era garantido no Estatuto dos Mercadores a Retalho exatamente com o argumento de que o comércio ambulante seria prejudicial à riqueza da nação e aos bons costumes ao definirem lugares de respeitabilidade para serem freqüentados (todas as lojas deveriam funcionar junto às calçadas e jamais em sobrados) e ao obrigarem os mercadores e seus caixeiros a freqüentarem as aulas de comércio para o ensinamento básico das atividades mercantis. Se o 
Alvará provocou assombro entre os mercadores do Brasil, não será diferente em Portugal.

A mudança do centro de decisão do Império provocou uma constrangedora situação para os mercadores portugueses e, é claro, para toda a elite formada por negociantes e membros da Junta. Tratava-se agora de obedecer às ordens emanadas a partir de uma terra distante e de seus costumes distintos. Portugal passou a ser designado por "domínios ultramarinos" e isso lhes parecia muito mais um ultraje. Por essa razão, o Alvará provocou uma longa batalha, ao longo dos anos de 1812 a 1826, de requerimentos de mercadores e pareceres da Junta de Comércio em torno da questão da liberação para o comércio ambulante, com a agravante de, no ano de 1813 , ter sido estendido às mulheres o direito de também participarem de tal comércio.

Até aquele período, às mulheres era permitido participar, apenas, com restrições, da classe de mercadores de retrós, sendo viúva ou filha (única herdeira) de um mercador registrado na Mesa do Bem Comum dos Mercadores das Cinco Classes. Também era permitido às mulheres comercializarem alguns produtos específicos para o uso feminino: Toalhas de Torres, franjas brancas de linha, coisas de linha e rendas da terra, ataduras de pano de linho, assentos de punhos, flores de seda e de penas, tigelas de cor e carmim, pomadas. Somados a estes itens, que só poderiam ser vendidos pelas mulheres, havia outros que, mesmo sendo vendidos por homens poderiam fazer parte das lojas comandadas por mulheres, eram: linhas de toda qualidade feitas no reino, meias de linha, luvas de linha, rendas feitas no reino, fitas de linho ou de nastro ${ }^{11}$ feitas no reino e botôes de linha ${ }^{12}$.

Apesar da proibição, abriu-se um precedente no ano anterior, em 1812, quando o Príncipe Regente lhes dera autorização para venderem as mercadorias restritas às cinco classes de mercadores, pois assim poderiam ajudar na subsistência da família em tempos de guerra ${ }^{13}$. As reações dos mercadores foram tão fortes, com a abertura de requerimentos à Junta para a anulação de tal prerrogativa, que, no ano seguinte, as comerciantes de Portugal se sentiram estimuladas a reunirem assinaturas de negociantes portugueses e ingleses, afirmando nada terem em contrário à participação de mulheres no comércio ambulante ${ }^{14}$. Anexada ao processo está uma carta do Procurador das suplicantes, Diogo Henriques: 
Chegam à presença de V. A R. essas infelizes, a quem pretendem aniquilar a Mesa do Bem Comum dos Mercadores (...). O Alvará de 27 de março de 1810 não é mais do que uma conseqüência deste mesmo tratado e da religiosa observância, com que V. A R. costuma cumprir as suas estipulações, e por isso, debalde se cansa a Mesa do Bem Comum em querer que a disposição seja somente aplicável ao Império do Brasil, lançando linha de separação entre as leis e os vassalos do mesmo soberano, (...). Segundo a hermenêutica da Mesa do Bem Comum uma legislação que derroga expressamente o monopólio das corporaçôes é somente aplicável ao Brasil, onde não há corporações e não se estende aos outros domínios de V. A R., onde existe esse flagelo: uma lei fundada no bem público e nas doutrinas dos mais sábios e mais ilustres escritores da Europa, não é aplicável à Europa; uma lei, enfim, que estende a sua benéfica disposição a todos os fiéis vassalos de V. A R., não se deve cumprir em Lisboa. Se a Mesa do Bem Comum e os seus satélites não se julgam compreendidos no número dos fiéis vassalos de V. A R., as suplicantes, muito pelo contrário, derivam toda a sua justiça deste honroso título que lhes compete e que fará sempre a sua felicidade. ${ }^{15}$ (grifos meus).

Acrescentamos aqui um complicador. Ao dizermos que por razōes distintas as leis elaboradas no Brasil desagradavam aos portugueses e aos americanos, simplesmente não contemplaríamos os lados "marginalizados" dos dois lados do Atlântico: ambulantes e mulheres. O que mais chama atenção na representação enviada pelas mulheres é o fato de elas se colocarem como fiéis vassalas, diversamente dos mercadores das cinco classes. Estes, ao contrário, se insubordinavam contra uma ordem régia. Para essas mulheres, não deveria haver diferenças entre as diversas partes do reino, pois não se devia separar, por linhas divisórias, vassalos e leis de um mesmo soberano. Também é bastante lógico o argumento de os princípios liberais, concebidos na Europa, não serem aplicados em um reino europeu, mas sim numa terra distante de outro continente.

Através das diversas representações e da longa disputa entre homens e mulheres em torno da extinção de privilégios, podemos perceber o grande conflito que se formava a partir do que era entendido como uma perversão da ordem estabelecida. Entre as representações e outros documentos da Mesa do Bem Comum dos Mercadores, submetidos à Junta do Comércio, podemos ver claramente que os varejistas portugueses não se sentiam inclusos no Alvará de 1810, o qual só se deveria ser aplicado ao 
Brasil, onde não existiam classes de mercadores. Para eles, o referido alvará não revogava importantes leis do reino ${ }^{16}$, as quais regulamentavam a atividade dos mercadores; por isso, "foi dado para os Estados do Brasil pelas circunstâncias ali ocorrentes", e "que é só particular para os mesmos Estados do Brasil" 17 . O maior argumento apresentado pelos comerciantes portugueses era o fato de o tão polêmico alvará expressar que as novas regras deveriam ser cumpridas em "todos os tribunais do Reino e deste Estado do Brasil". Portanto, ao estabelecer o alcance da lei como "Deste Estado do Brasil e Domínios Ultramarinos”, Portugal, a metrópole, não estava incluída. Com freqüência, durante o processo, a Junta de Portugal queixava-se de ter perdido o poder de arbitrar sobre as decisões que envolvessem apenas Portugal. Em 1820 ela emite um parecer que, com desdém, refere-se ao pouco que se pode fazer "sobre os defeitos de uma administração estabelecida em país tão remoto, e de cuja organização e atos administrativos só constam os poucos documentos produzidos por estas partes"18.

No ano de 1826, um volumoso processo reúne os principais documentos da batalha travada pelos mercadores das cinco classes desde a transferência da Corte $^{19}$. O processo é documentado com os estatutos das cinco classes de 1757, com as demais leis subseqüentes e com o edital de 1813, que autorizava as mulheres a participarem do comércio ambulante. Antes desta data, porém, em documento de junho de 1812, os mercadores estabelecidos de Lisboa ainda tentam intimidar a participação das mulheres, alegando, principalmente, a dissolução de costumes, a ilegalidade e a má influência dos hábitos mercantis brasileiros. Retomando os princípios da jurisprudência romana, lembraram que, desde os "tempos de Augusto", os romanos já se acautelavam em relação às negociaçôes e aos contratos de mulheres, consideradas inábeis para esses fins. Argumentavam, também, que as ordenações portuguesas, baseadas no direito romano, proibiam a participação das mulheres no comércio, exceto em casos especiais. Citam o Tomo 61, do Livro 4, e o Tomo 101, do Livro 5, nos quais se determinava que, pela "fraqueza do entender das mulheres", elas somente poderiam vender massas para doces e selos, coisas de "pouca monta". Isso porque "os homens[,] com o seu sexo, merecem com a mira na agricultura e na defesa do reino" não servirem "ao luxo e à gula". Mesmo assim, nos séculos posteriores, "menos asiáticos no encerro das mulheres", os portugueses toleraram que as mulheres se empregassem em 
coisas que tivessem "analogia com suas forças e sexo". Afirmavam que até mesmo a prática das "adelas", que vendiam vestidos e roupas usadas - as novas eram exclusivas dos mercadores -, já se encontrava prevista nas ordenações do reino ${ }^{20}$. Por isso, as regulamentações criadas para o Brasil referido quase sempre como um lugar longínquo e pouco conhecido não se adequavam a Portugal, onde a honra e os bons costumes no comércio se mantinham devido aos estatutos.

A nossa legislação regulou o comércio interior dos gêneros das cinco classes deu-lhe estatutos com que tem florescido, e os longos anos lhe têm posto o selo: o que o providente soberano ordenou em um diverso, e nascente império, não parece, por isso mesmo, acomodado a este reino, pela mesma razão que os estatutos deste reino não parecerão moldados para aquele. Acresce que, contando estas classes, depois da sua regeneração, além de 55 anos, se tem criado famílias honestas e fundado casas dependentes unicamente deste comércio interno. ${ }^{21}$

\section{Portugal: o outro lado do Império}

Em Portugal, a Junta de Comércio, representante da Mesa do Bem Comum dos mercadores, tende a concordar com os mercadores e com a manutenção do privilégio das classes mercantis, tornando-se desfavorável à legislação elaborada no Rio de Janeiro, embora não pudesse se opor à autoridade de D. João VI. Segundo Madureira, a Junta do Comércio em Portugal foi permeável às idéias mercantilistas, fisiocratas ou liberais, mas foi, sobretudo, uma instituição absolutista no modo de se relacionar com a sociedade e nas formas de cultura política centradas no Estado. Para ele, o papel da Junta era o de continuidade, apesar do seu caráter reformador. Quanto ao mercado, Madureira diz que a Junta seguiu os paradigmas da economia liberal, sendo que acreditava na "convergência espontânea e natural entre o interesse particular e o interesse coletivo". Entretanto, a mão invisível que assegurava tal convergência não se encontrava somente no mercado, "a necessidade de reformas obrigam a uma política esclarecida de intervenção sustentada na economia. É o Estado que deve compatibilizar os interesses particulares e coletivos" (MADUREIRA, 1997:72-78). No ano de 1822, pressionados pelas Cortes Gerais, os mercadores das cinco classes exigiam 
que seus privilégios não fossem abolidos. Através de carta remetida à Junta, eles se queixavam das irrestritas liberdades concedidas ao comércio e enfatizavam o quanto isso era pernicioso à agricultura no que dizia respeito aos homens. Em relação à mulheres, eles alegavam que elas deveriam se empregar em outras atividades que eram "igualmente mais interessantes à sociedade, como, por exemplo, servirem de criadas, usarem dos lavores e indústrias próprias do seu sexo e serem empregadas nos trabalhos das fábricas que forem com eles compatíveis". ${ }^{22}$

O Procurador das mulheres, Diogo Henrique, procurou rebater cada uma das queixas feitas pelos mercadores. No que dizia respeito às perdas econômicas que eles sofriam com a "desonesta concorrência", ele fez um cálculo da população de Lisboa proporcionalmente ao número de estabelecimentos comerciais. Para ele, Lisboa e seu termo tinham à época, 1813, cerca de 400.000 habitantes para uma média de 85 lojas em cada uma das classes e isso deixaria uma reserva de pelo menos 5.000 consumidores para cada um dos lojistas. Ele considerava, portanto, que isso era um terrível monopólio e que, além disso, não havia registros de pedidos de falências. Pelo contrário, o que se via era a grande opulência com que viviam os mesmos mercadores. ${ }^{23}$

A não resolução desse impasse para os mercadores, isto é, da inclusão de ambulantes e mulheres em seus negócios, é agravada pela permissão de novos concorrentes: alfaiates e modelistas. Neste ponto, é necessário discutirmos outros elementos que vão além da concorrência e do privilégio: trata-se da reserva de mercado para as produçóes nacionais amplamente sustentadas pelas leis suntuárias. Como se sabe, as leis suntuárias previam a redução ou eliminação do que era considerado luxo, ou, em outras palavras, supérfluo. Neste contexto específico, essas leis serviam para barrar produtos estrangeiros considerados "supérfluos". No Alvará de 27 de março, anteriormente citado, essa questão já aparece como um empecilho às novas tendências econômicas, isto é, a liberalização total do comércio. Dizia-se naquele documento que a experiência já havia provado o quanto era inútil a pragmática suntuária, pois só faziam diminuir o comércio e a produção na sua proporção, segundo os critérios dos "verdadeiros princípios de economia política”.

Vejamos mais atentamente essas questôes. Os mercadores das cinco classes podiam vender roupas feitas, tecidos do reino, preferencialmente, 
e tecidos estrangeiros quando não havia substitutivos. As adelas, como dissemos acima, podiam vender roupas usadas apenas. Para que um consumidor tivesse uma roupa feita sob medida, deveria procurar um alfaiate ou uma modelista, os quais não deviam ter lojas nem utilizar apenas tecidos estrangeiros, pois o uso de tecidos caros, seguindo-se tendências da moda, era considerado um abominável hábito alimentado pela ostentação e o luxo ${ }^{24}$.

Os mercadores das cinco classes diziam haver uma grande confusão entre a arte e a mecânica. Os alfaiates, diferentemente dos algibetes que costuravam com panos baratos para uma freguesia pobre e sem recursos, necessitavam de tecidos finos e caros, pois atendiam uma clientela refinada. Por essa razão, não poderiam correr riscos ao comprar sua matériaprima por preços mais altos nas mãos dos mercadores e ter prejuízos com um corte mal feito ou uma ruga na costura.

Tem por concorrentes, e compradores, mancebos presumidos, ricos, nobres, fidalgos, (e ainda mulheres) todos caprichosos, escravos das modas, e até supersticiosos, aclamadores dos feitios; por uma suspeitada ruga em um calção rejeitaria o mancebo, todo um vestido de seda de novíssimo gosto, ou do veludo de maior preço. Pode, rara vez, concorrer algum aldeão presumido, ou casquilho pobre, que haja de aproveitar um vestido sem medida, ou algum já refugado, mas não é esta curta e incerta utilidade que se busca para converter a casa do alfaiate em loja, e o artífice em mercador, encomendando em Inglaterra e França, sacando e pagando letras e ostentando junto à casa de medidas, o escritório das correspondências, o armazém dos atacados, e os armários dos vestidos feitos. Na política e no comércio, propõem-se aparências e ocultam-se as realidades, e muito mais as estudadas conseqüência. ${ }^{25}$

Para os mercadores, os alfaiates eram artífices e não deveriam meterse em negócios, pois seu ateliê não poderia transformar-se em loja e passar a vender mercadorias prontas, ainda que feitas com tecidos de alta qualidade. Os mestres alfaiates passavam a vender o "fato-feito" e também tecidos como lã e seda; e isso seria contrário ao regimento dos mercadores. Esses "fatos-feitos" seriam, segundo os varejistas, "enganosamente mais baratos", pois se os alfaiates deixavam de comprar os tecidos em suas mãos, comprando-os diretamente das fábricas, deixariam os queixosos na ruína. Para eles, era isso que significava a confusão das artes com a mecânica, 
pois a atividade mercantil e mecânica não deveria ser confundida com a arte da costura dos alfaiates e toda essa confusão derivava das irrestritas liberdades definidas a partir do Reino do Brasil.

Já os alfaiates rebatiam aos requerimentos dos varejistas junto ao Senado da cidade de Lisboa em 1819 e alegavam que a justificativa dos mercadores era "com efeito a obra do maior empenho do sofisma que se tem imaginado". Para refutá-la apresentam cinco argumentos derrubando cada uma das queixas apresentadas. No primeiro, contestam a idéia apresentada pelos mercadores segundo a qual as obras feitas à mão e em proveito de quem as fazem é assunto do Senado, assim como vender obras feitas por outrem é da jurisdição da Junta de Comércio, por isso, pediam ao Rei o direito de venderem obras feitas como o fazia qualquer corporação, cujos regimentos eram atribuídos pelo Senado. $\mathrm{O}$ segundo argumento contestava a insinuação de serem facilitadores de contrabando, pois eram rigorosamente vigiados, cabendo essa desconfiança à atividade dos algibetes aqueles que produziam e vendiam roupas de qualidade inferior. No terceiro ponto defendiam-se da queixa de não comprarem tecidos dos mercadores e de venderem muito caro suas mercadorias a fregueses muito caprichosos. Argumentavam que tal afirmação era desrespeitosa com seus clientes que só faziam aumentar o giro do comércio, nada mais. Na quarta contestação os alfaiates recusam serem responsabilizados pela "ruína" dos mercadores, pois isso seria um contra-senso na medida em que aqueles eram privilegiados em seus estatutos. Finalmente, afirmam não serem também responsáveis por prejuízos ao Estado, uma vez que:

(...) Não há transtorno da economia dos mercadores, senão em não serem depositários do grande monopólio de que querem fazer o público de tributário. Não há confusão das artes mecânicas, porque os alfaiates já há mais de três séculos contados como os mais oficiais mecânicos, cujos materiais conservam nas suas lojas, sem que lho dêem os fregueses e os algibetes concorrem aos leilōes sem oposição aos suplicantes. ${ }^{26}$

Os alfaiates logram seu intento ao conseguir junto ao Senado no ano de 1823. Mesmo assim, os mercadores insistiam em suas queixas. Para eles, transformar o artífice em mercador era, portanto, confundir as artes mecânicas; era subverter a ordem dos ofícios e impedir que os "verdadeiros mercadores" pudessem continuar a vender seus tecidos. Noutras pala- 
vras, eles não mais teriam bons fregueses, contariam apenas com aqueles que não poderiam pagar pelos serviços de um alfaiate ou de uma modista, ou mesmo de comprar uma roupa pronta feita com cortes e tecidos da moda.

Também as modelistas ou modistas seguiam o mesmo caminho dos alfaiates. Essas prejudicavam especificamente as classes de capela, pois vendiam seus gêneros privativos

(...) debaixo da aparência de que os tem só para ornatos e enfeites dos vestidos que fazem, quando verdadeiramente suas casas são menos uma oficina de trabalho, que um armazém de rico e variado negócio, cheias de peças de seda, fitas, volantes e todas as mais e infinitas coisas desta ordem, algumas do país e a maior parte de contrabando, com que lisonjeiam o gosto, vaidade e capricho do sexo apetitoso. (...) [causam] a ruína da indústria nacional por motivos dos contrabandos, e dano gravíssimo da sobredita classe que sofre o empate de seus gêneros, vê passar as modas, perde a venda desses efeitos, que não tornam a ter valor (...).

Aqui os queixosos mercadores apelam para duas questóes importantes nos princípios que separavam as duas Juntas de Comércio do Brasil e de Portugal: o monopólio das produçôes nacionais e a liberdade de seguir a moda. É curioso lembrar, neste caso, uma correspondência trocada entre José da Silva Lisboa, Visconde de Cairu, e Domingos Vandelli, membro da Real Academia de Ciências de Lisboa. Quando representante da Mesa de Inspeção da Bahia, substituída pela Junta de Comércio, Cairu enviou a Vandelli amostras de plantas e produçōes agrícolas de sua capitania junto a uma descrição pormenorizada da cidade da Bahia, seu povo e costumes. Dizia sobre as mulheres, que elas não poupavam meios de satisfazer a vaidade em suas vestes e ornamentos, mesmo quando o interior das casas era "excessivamente modesto e despojado". O futuro Visconde de Cairu não se conformava com o gosto extravagante das mulheres na colônia, as quais, com raras exceçôes, "excediam as européias" no gosto de variar enfeites.

O ornato feminil é excessivo e rico, porém de mau gosto; consta de muita seda, muito galáo de ouro, apresentam-se como tabuletas carregadas de ouro e ainda com a indecência nauseoza de uma camisa bordada, que lhes deixe ver o peito todo, indignidade que, contudo, não ofende os olhos das gentes do país, porque são muito aferrados aos costumes bárbaros dos antigos indígenas. ${ }^{27}$ 
Como membro influente da Junta após a transferência da Corte, o liberal Visconde de Cairu certamente apoiava a eliminação das leis suntuárias e o consumo vaidoso das mulheres na América. Seja como for, não estamos dizendo que as mulheres portuguesas não gostavam de se vestir de acordo com a moda, mas que a pressão das corporações de mercadores certamente tentavam impedir esse consumo apelando para as pragmáticas suntuárias e para a necessidade de se comprar apenas produtos nacionais, geralmente rústicos.

O grupo corporativo de comerciantes arrogava a permanência das leis suntuárias para lhes preservarem os mercados com a justificativa de que o luxo, como supérfluo, em nada beneficiava o comércio e, além disso, pervertia os bons costumes das famílias honestas. Entretanto, não era essa a definição que os dicionários de comércio correntes da época davam ao termo. $\mathrm{O}$ mais famoso dicionário de comércio foi editado, pela primeira vez, no início do século XVIII, entre 1723 e 1730: Dictionnaire universel du commerce, d'histoire naturelle et des arts et métieres, por Jacques Savary dês Bruslons ${ }^{28}$ definia o termo mais amplamente. Essa obra foi traduzida para o português em 1813 pelo segundo lente da aula de comércio em Lisboa, Alberto Jacqueri de Sales. Não foi apenas uma simples tradução, mas uma adaptação daquela obra às condições econômicas e comerciais de Portugal, contendo, em seus quatro volumes manuscritos, regras gerais do comércio interno e, principalmente, externo.

Vejamos o que diz esse dicionário acerca do termo luxo: inicialmente o autor diz que o luxo sempre foi tradicionalmente identificado como o que é supérfluo nos gastos, pois como já diria o famoso Padre Vieira, "todos aspiram ao supérfluo e isto é o que se chama luxo"; logo a palavra seria imediatamente associada à idéia de consumo. Conseqüentemente, a perspectiva de consumo desnecessário fortaleceu um princípio moral de que o homem honesto deve levar uma vida modesta e frugal e, por essa razão, o luxo era um mal e deveria ser combatido, entretanto o autor nos diz que o sentido de luxo deveria ser pensado de forma relativa, isto é, o que nos induz é nossa propensão natural à comodidade, "de modo que as comodidades que fazem mais segura a nossa conservação parecem um grau fixado pela natureza entre as necessidades físicas e o luxo". Logo, a nossa propensão natural nos impulsiona sempre a procurar uma vida melhor, mas nem todos conseguem e isso gera, naturalmente, uma diferença 
entre os homens. Ele traduz: o luxo é "o uso que os homens fazem da faculdade de existirem gostosamente pelo trabalho alheio". Mas isso não seria ruim, mesmo que nem todos conseguissem, a busca pelo bem-estar geraria grandes indústrias e fomentaria o comércio.

Na proporção que esta repartição se vai repetindo, o lavrador e o artífice se facilitam um maior número de comodidades gostosas, cujo uso multiplica as mesmas faculdades nas outras classes. A desigualdade, contudo, que permanece entre cada classe, não desanima os homens porque eles conhecem o seu princípio e sabem que é a indústria que está ao alcance de todos.

Max Weber veria aí o "espírito" do capitalismo entrando em ação contrariamente à permanência dos usos e costumes tradicionais, corroendo e destruindo a rusticidade de uma vida frugal, entretanto, sabemos que a defesa das liberdades irrestritas de mercado sempre foi uma das facetas do capitalismo moderno, à qual originalmente é associado. Sabemos, por outro lado, que o monopólio e o corporativismo são outras importantes facetas deste mesmo sistema econômico e que fazem parte do jogo do mercado.

Daí decorre a dubiedade das ações e discursos dos representantes da Junta de Comércio que conjugavam sociedades regidas por costumes e características de Antigo Regime com a defesa ardorosa de práticas de mercado liberais. O problema é que, exatamente pelo fato de serem sociedades de Antigo Regime, onde não havia disputa de classes hegemônicas burguesas, oposição aos privilégios e a luta por liberdades individuais contra a tradição e a hierarquia, o discurso liberal era combatido exatamente por aqueles que o deveriam defender, a elite mercantil e os homens práticos do comércio, lembrando que na América a escravidão e toda a relação de subordinação e dependências pessoais seria um dos grandes obstáculos à construção de um capitalismo liberal. Entretanto, os projetos reformistas da Corte portuguesa para o Brasil apontavam para se estabelecer aqui práticas de mercado mais liberais, sendo aqui um "país do comércio".

\section{Os dois lados do Império: correlação de forças}

De toda a polêmica resultante do Alvará de 27 de março de 1810, tanto nas praças comerciais de Portugal como do Brasil, especialmente 
pelos comerciantes do Rio de Janeiro, é interessante observamos que o entendimento das práticas comerciais restritas era respaldado pela legislação suntuária e pela nacionalização do mercado. Assim, as corporações de mercadores estariam resguardadas em suas mercadorias específicas e de produção nacional até o momento em que as importações de manufaturados são abertas, assim como é dada a permissão oficial a outros grupos de mercadores. A idéia de que a liberação do comércio de mercadorias a ambulantes - homens e mulheres - e artífices iria perverter toda uma tradição baseada nos usos e costumes, bem como diminuiria as rendas públicas e incentivaria o consumo de artigos de luxo, está, de certa maneira, ligada ao discurso da "economia moral" na Europa moderna.

$\mathrm{Na}$ Corte do Rio de Janeiro, a insatisfação dos comerciantes varejistas não era diferente. Infelizmente não temos, como no caso da Junta de Comércio de Portugal, nenhuma representação de ambulantes, mulheres ou alfaiates, apenas as inúmeras queixas dos mercadores remetidas à Junta do Rio de Janeiro para reivindicar as mesmas prerrogativas e exclusividades dos mercadores portugueses. Defendendo seus interesses específicos, os comerciantes estabelecidos em lojas opunham-se não só ao comércio ambulante, mas também à possibilidade de os artífices, ou, no caso, os alfaiates e fabricantes, venderem eles próprios os seus produtos. Nesse ponto, o pedido dos mercadores brasileiros em nada diferia dos pedidos dos mercadores das cinco classes de Portugal.

No ano de 1817, um grupo de comerciantes a varejo envia, através do Desembargador e Juiz Conservador dos Privilegiados do Comércio, um requerimento à Junta - na verdade, a ela se dirigiam pela segunda vez -, solicitando a proibição do comércio ambulante, a proibição de estrangeiros no comércio local e o fim dos leilóes de comerciantes falidos ${ }^{29}$.

Quanto à proibição de ambulantes, o grupo alegava que a concorrência desleal fez com que deixassem de obter lucros e, assim, deixaram de contribuir com impostos e, até mesmo, tornaram-se eles próprios contrabandistas e sonegadores por terem sido compelidos a isso. Para esses comerciantes, os mascates não possuíam capital ou crédito e, por isso, não tinham nada a perder, mesmo porque não precisavam pagar impostos, o que tornava o seu lucro muito maior. Além disso, não tinham os mascates fé pública, ciência ou experiência, elementos que eram a base dos princípios mercantis. Diziam os comerciantes que, por um cálculo pouco de- 
purado, tal liberdade de mercado dava a "aparência" de menores preços devido a uma errônea interpretação das máximas "liberdade e proteção". Para eles, essas máximas deveriam ser substituídas por "proporção e proteção". Segundo alegavam, os mascates vendiam por um preço nominal mais baixo, mas por um preço real mais alto. Isso porque vendiam mercadorias inferiores como se fossem as melhores, e os consumidores, não tendo forma de compará-las, como poderiam fazer em lojas, eram enganados. Assim definiam os seus concorrentes:

Homens precários, sem estabelecimento e sem representação, um reduzido quarto em ignóbil casa, lhes oferece cômoda moradia, uma tasca lhes oferece alimento pronto, qualquer roupa os veste. Mal provido, tabuleiro carregado sobre as costas de um negro, faz toda a sua tenda, as suas estantes, o seu mostrador; as ruas, as suas lojas. Jamais o resultado de seu tráfico apareceu ao público pela circulação de seus lucros e jamais o fabricante, o artista, o operário tirarão algum interesse de seu desmarcado supérfluo, aplicado muitas vezes a sinistros usos. ${ }^{30}$

Boa parte da queixa dos mercadores da praça do Rio de Janeiro decorria do fato de que a instituição da Junta de Comércio no Brasil tinha como princípio, segundo o já citado alvará de 23 de agosto de 1808, a determinação de se criar uma Junta dentro das mesmas leis e estatutos com os quais foram modificadas a Junta de Comércio em Portugal em 1788. Isto queria dizer que os mercadores varejistas no Brasil teriam os mesmos direitos e deveres aplicados em Portugal, incluindo a obrigatoriedade de se matricularem em aulas de comércio e de se profissionalizarem. Por essa razão, eles contrapunham os seus "saberes" e suas obrigações fiscais à liberdade "pouca ciência” dos mascates.

É interessante, também, ver como reconhecem o sentido de "valortrabalho" das mercadorias para demonstrar que a atividade ambulante é ilegal, pelo fato de não gerarem novas fontes de riqueza e de trabalho. $\mathrm{O}$ fabricante, o artesão e o operário não lucram com a venda, o Estado também não, devido à não arrecadação de impostos. Por isso, segundo os varejistas, os baixos preços das mercadorias não contemplariam o custo de trabalho e os impostos agregados ao valor final do produto, não correspondendo, portanto, a atividade mercantil à sua abrangência "social".

Esses varejistas, no entanto, teriam que pagar por terem um comércio regular, "crescidas rendas de casas e lojas, avultados salários a seus cai- 
xeiros, a manter uma representação pública, a qual lhes corresponde a sustentar numerosas famílias". Em resumo, acusam os ambulantes de concorrência desonesta, prática ilegal de mercado. Assim, os ambulantes venderiam por um "preço mais alto relativamente ao Bem-comum", isto é, em longo prazo impediam o estado de arrecadar e de fazer obras públicas. Quanto à máxima da economia política de "liberdade e proteção", ela era mal interpretada, segundo os comerciantes varejistas.

O comércio não é a razão de sua extensão, e sim na sua perfeição, que se torna capaz de produzir o desejado Bem-comum. Assim como nos princípios de mecânica, não é na razão dos volumes, mas sim na de sua perfeição que as máquinas se tornam capazes de por em movimento massas maiores ou menores. Nem ao público interessará em que haja somente muitos, mas em que haja muitos e bons negociantes ${ }^{31}$.

Por isso, recomendam a proporção e a proteção: deve-se ditar proporção aos negociantes e liberalizar-lhes, a par dessa, a proporção. Sem mais argumentos, eles passam a invocar a legislação. Começam com o Alvará de 1755, que determinou a criação da Junta de Comércio em Portugal, e seguem com o Alvará de 1760, sobre as aulas de comércio, a necessidade de separação dos comerciantes por classes e a necessidade de profissionalização.

Eles [os alvarás] reconhecem o prejuízo que se segue de se introduzirem no comércio pessoas ignorantes do mesmo, e destituídas dos meios necessários para o cultivarem. As quais não tendo, nem inteligência para traficar, nem cabedal, ou crédito que perder, não só arruínam a fé pública, mas também os interesses dos particulares dos negociantes, do que se seguem quebras, e perturbações no comércio. ${ }^{32}$

Dizem os varejistas que, pelo Alvará de 16 de dezembro de 1757, que confirma o estatuto dos mercadores a retalho, estabelece-se o dogma mercantil pelo qual não se pode exercitar a ocupação de mercador sem que se possuam dois requisitos básicos: fidelidade e ciência.

Invocam também o Estatuto da Junta de Comércio de Lisboa, no qual se estabelece que o aumento e a dilatação do comércio, assim como da "mercadoria em grosso" e das vendas "em miúdo", constituem os elementos de felicidade do Reino. Por esse Estatuto, dizem os comerciantes, reconhece-se, também, que o segredo é necessário no manejo do comér- 
cio e isso não é possível com a ação dos mascates, embora eles não impeçam a dilatação do comércio. Representam o fim do "elemento nervoso" da atividade mercantil com suas indiscrições, revelando os segredos comerciais.

Os varejistas lembram, também, que o mesmo Estatuto e até mesmo a "liberalíssima" Carta Régia de 28 de janeiro de 1808 definem a necessidade de se pagar impostos nas alfândegas e de não se trabalhar com mercadorias fraudulentas. Não satisfeitos, esses varejistas citam um grande número de leis do Reino, anteriores à década de 1760, nas quais se proíbe veementemente todos os tipos de comércio volante ${ }^{33}$. Finalmente, pedem a derrogação do Alvará de 27 de março de 1810, visto que a experiência de sete anos de sua aplicação levou apenas à ruína do comércio regular. Reiteram que, pelos verdadeiros princípios de economia política, o comércio não exige liberdade absoluta, mas, sim, proporção e proteção. Porém não querem que os ambulantes sejam simplesmente excluídos da concorrência, mas que se enquadrem nas regras de mercado e passem a ter os mesmos deveres que têm os suplicantes. Esse mesmo alvará de 27 março, que facultava a qualquer pessoa "de qualquer qualidade" vender a retalho nas ruas e suas casas, definia expressamente que "o Alvará de criação da mesma Real Junta neste Estado [Brasil], e a continuação das restrições, (...) lhes é desfavorável, da taxa dos preços, e limitação de classes e mercadorias, na conformidade dos mesmos estatutos" estava equivocado e, portanto, derrogava as leis anteriores para estabelecer a liberdade geral a todos os vassalos do Reino.

Podemos evocar aqui uma questão muito importante apresentada por António Manuel Hespanha (2001:172): o direito pluralista da monarquia portuguesa com suas partes. Ele chama atenção para a recorrência do direito comum na Europa e da inconsistência do direito colonial moderno. Mesmo não tratando de um direito colonial, posto que a maior parte desta polêmica decorre exatamente do fato de leis emanadas a partir do novo Reino Unido do Brasil para os "Domínios Ultramarinos", a questão da inconsistência e do apelo aos usos e costumes foi um forte apelo para as questôes de jurisprudência. Hespanha diz que a prevalência do direito comum, baseada na preferência das normas particulares às normas gerais, tornava fácil a interpelação de novas leis, mesmo que se estabelecesse que a nova lei derrogaria a anterior. Para Hespanha, os "direitos adquiridos à sombra do anterior regime podiam ser opostos ao novo e quaisquer decisões reais que 
os violassem poderiam ser anuladas judicialmente" (HESPANHA, 2001:172). Por essa mesma razão, comerciantes varejistas dos dois lados do Atlântico apelam aos tribunais da Junta baseados nos usos e costumes adquiridos, embora no caso dos comerciantes da Praça do Rio de Janeiro pudéssemos falar dos usos e costumes que gostariam de adquirir, mas essa era muito mais uma questão de retórica.

Voltemos, portanto, ao processo dos mercadores do Rio de Janeiro. Junto com o requerimento dos comerciantes, segue um parecer do próprio Desembargador e Juiz Conservador dos Privilegiados do Comércio, Antônio Pinto de Madureira. Ele concordava com todos os pontos alegados no requerimento dos varejistas, enfatizando alguns deles, especialmente no que dizia respeito à proibição de estrangeiros e de importação ilegal de mercadorias no Brasil. Para ele, a economia não era um sistema, por se tratar de princípios variáveis, sujeitos à circunstância. Assim, ele via o Alvará de 1810 como uma legislação que atendia a interesses momentâneos e a impressões passageiras, tal como era falsa a alegada comodidade dos consumidores, os quais não precisariam sair às ruas para fazer suas compras. Isso, ao seu ver, levava os poucos consumidores a comprarem mercadorias sem um valor "real intrínseco", gastando o que talvez poupariam se os ambulantes não fossem às suas casas.

Em resposta ao requerimento dos comerciantes varejistas e ao parecer do Juiz Conservador, o Juiz Fiscal encerra o processo de consulta ao tribunal da Junta. Para ele, os suplicantes apenas queriam tirar a concorrência de competidores, abarcando, assim, todas as fazendas para monopolizarem e imporem preços exorbitantes. Enfatizou que o interesse maior do Alvará de 1810 era justamente o de promover o bem geral de todas as classes de intermediários, para a comodidade dos que habitavam em lugares mais distantes. O Juiz Fiscal lembra-se do requerimento anterior, que havia sido indeferido, e diz que o segundo era igual ao primeiro, à exceção de ser mais "pomposo" e conter mais assinaturas e também pelo fato de conter uma "indecente contradição do liberal sistema" que se tinha adotado no Brasil. Segue contra-argumentando que a atuação dos ambulantes servia muito bem à comodidade dos consumidores, os quais não precisavam deixar seus afazeres domésticos e que, além disso, a atividade dos mascates era regulamentada e fiscalizada pelos fiscais de polícia e pela Real Fazenda. Informava ainda que não tinha notícia de falimentos de varejistas; muito pelo contrá- 
rio, sabia que nenhuma casa havia sido fechada, assim como muitas outras estavam sendo abertas. Segundo sua lógica, sobressaíam-se aqueles comerciantes que ofereciam boas mercadorias e preços moderados. Para o Juiz Fiscal, a obtenção de lojas e casas comerciais era a evolução natural de todo o mascate que se enriquecia, não havendo outro motivo para os suplicantes a não ser o medo da concorrência.

Nem era possível que, havendo incomparavelmente maior importação de fazendas, deixasse também de haver maior número de distribuidores, particularmente nesta Corte que está dia a dia crescendo em edificação de casas e extensão de subúrbios, o que muito dificulta aos moradores remotos o virem fazer suas compras nas ruas e lojas antigas. A experiência tem mostrado que os vendedores por miúdo, logo que podem, se estabelecem com alguma loja em lugar proporcionado ao cômodo do povo e com os suprimentos mais comuns e de alcance das faculdades dos vizinhos. Costumam os indivíduos ricos, ou abastados, ir sempre comprar as maiores importâncias nas grandes lojas das ruas dos moradores. Isto é conforme a ordem natural das coisas e se executa sem necessidade de regulamento. ${ }^{34}$

A partir desse momento, a resposta do Juiz Fiscal aos requerentes se torna mais incisiva, pondo em questionamento a própria posição classista dos varejistas. Questiona a ameaça dos requerentes de condicionarem ao seu sucesso comercial a garantia de empréstimos e financiamentos ao Estado, o que os distinguia dos "negociantes de grosso trato", esses, sim, capazes de adiantar os direitos das mercadorias com atividades de maior risco. Além disso, diz que os varejistas ostentavam ciência de comércio e de governo, mas não demonstravam as habilidades aprendidas nas aulas de comércio. Considerava absurda a insistência dos comerciantes para que se aplicassem no Brasil as mesmas leis aplicadas em Portugal, pelo fato de aquele reino ser "tão diversamente circunstanciado em antigüidade de estabelecimentos" ${ }^{35}$. Dizia, também, que no Brasil os usos e os costumes eram diferentes pelo fato de não "irem as mulheres comprar fazendas em lojas, exigindo a prudência política e manutenção dos costumes, que só o tempo e o progresso do polimento do povo faz mudar". Neste caso específico, é pena que o autor do argumento não dê maiores detalhes de seu raciocínio, pois, como vimos anteriormente, os comerciantes portugueses queixavam-se de que a entrada de mulheres no comércio ambulante era, para eles, um reflexo da dissolução dos costumes, algo comum no Brasil. 
Além disso, segundo o Juiz Fiscal, buscava-se, no Brasil, diminuir os rigores das leis que eram aplicadas em Portugal, devido ao fato de ser esse Estado, "na maior parte, um país de comércio" e de aqui se aplicar, sem restriçôes “a iluminada economia política”. Lembrava que o Rei D. José já dizia que as leis devem ser aplicadas de acordo com as circunstâncias e os lugares. Concluindo o processo, a Junta envia a D. João VI o parecer desfavorável ao deferimento do pedido dos comerciantes varejistas. $\mathrm{Cu}$ riosamente, essa fala do Juiz Fiscal da Junta do Rio de Janeiro, que de certa forma confirma o que dissemos acima sobre a pluralidade jurídica, não se detém sobre os contratempos que essa mesma legislação provocava em Portugal. Parecia não haver qualquer correspondência entre as duas casas, embora a segunda fosse subordinada à primeira.

Quatro anos depois, em 1821, os mesmos comerciantes enviaram o quarto pedido, o qual continha as mesmas alegações anteriores. Acrescentavam, porém, em resposta aos pedidos negados que: em primeiro lugar, os consumidores nunca compravam "senão com o fim de suprir as suas necessidades reais ou fictícias” e que, se eles já tivessem comprado nas mãos dos ambulantes, não iriam procurar as lojas. E, em segundo lugar, as lojas podiam ser estabelecidas em qualquer lugar, até mesmo nos lugares mais distantes dos grandes mercados ${ }^{36}$. Buscam exemplos de precedentes, como o dos sapateiros, que conseguiram a proibição de se vender sapatos nas ruas, e dos mercadores de pano de Portugal, que conseguiram idêntico benefício.

A resposta dada a esse novo requerimento também não destoava dos processos anteriores, como o próprio parecerista enfatizou. Entretanto, é interessante notar que ele demonstrava a não diferenciação de classes mercantis no Brasil, ao contrário do que acontecia em Portugal.

Cumpre dizer que o Alvará de vinte e sete de março de mil oitocentos e dez legislou somente para o Brasil, onde se precisava aumentar o comércio, que as circunstâncias então exigiam, e, onde não havendo ainda repartição de classes, era penoso e opressivo o estabelecer-se, pois que certamente faria grande transtorno a execução do Regimento, e Alvará, cuja restauração hoje, instam aqueles mesmos, que talvez a maior parte deles, que se acham assinados, fossem obrigados a fechar as suas lojas por não se verificar neles os requisitos do dito regimento. ${ }^{37}$ (grifos meus) 
Ora, o argumento do Juiz Fiscal da Junta do Brasil era o mesmo dos mercadores das cinco classes em Portugal, isto é, a legislação que promovia o comércio ambulante para ambos os sexos deveria ser aplicada somente no Brasil. Neste sentido, o argumento das mulheres comerciantes em Portugal que diziam não haver distinção entre as leis e os vassalos de um mesmo reino, caía por terra. Certamente Brasil e Portugal eram terras distintas, mas, por razões diversas, grupos de homens e mulheres arrogavam a verdadeira unidade. A questão, na verdade, não era somente a inexistência de diferentes classes mercantis no Brasil, e a própria Junta deixa isso claro ao distinguir os varejistas dos "negociantes de grosso trato". Acontecia que no Brasil não havia estatutos que, legalmente, os distinguissem. Os estatutos existentes em Portugal não poderiam ser aplicados no Brasil, de acordo com os juizes da Junta do Comércio, uma vez que aqui foram adotados procedimentos mais liberais no comércio do que na própria Metrópole e, além disso, deveria ser evitada a formação de estruturas corporativas, consideradas como um "mal necessário" em Portugal. Como vimos acima, a Junta de Comércio constituiu-se no fórum especial dos "homens de negócio", tendo a Mesa do Bem Comum dos Mercadores de retalho como subordinada. Dessa maneira, todas as questões do comércio a varejo eram arbitradas pela Junta, embora a distinção entre esses dois grupos não fosse apenas de classe. Embora Jorge Pedreira reconheça que nem sempre fosse fácil definir com absoluta precisão as categorias do vocabulário social devido à fluidez dos corpos mercantis como a possibilidade de mercadores estabelecidos se elevarem à condição e homens de negócio ou estes manterem lojas abertas - a fratura que se situava entre estes dois grupos estava no capital, no crédito, na multiplicidade de interesses comerciais e na instrução ${ }^{38}$. No referido dicionário de Jacques de Savary encontramos as seguintes definiçôes para estes grupos: os homens de negócio se distinguiam pelo "comércio em grosso", sendo essa uma profissão muito útil por ser a alma da navegação e a fonte de riquezas para uma nação. Quanto ao comércio a varejo, temos a definição do mercador como aquele que compra e vende. "Esta palavra [mercador] se diz no idioma portuguez peculiarmente dos que tem logem (lojas) abertas e que vendem a retalho" ${ }^{39}$. Essas distinções foram fundamentais em Portugal e no Brasil, embora aqui, como dissemos, a inexistência dos estatutos dos mercadores tornava-se uma dificuldade para aqueles que queriam se estabelecer dentro dos privilégios. 
Para o correspondente do Correio Braziliense, Hipólito José da Costa, as confusões e os conflitos gerados na interpretação e na aplicação das leis por parte da Junta do Comércio derivava da divisão dessa instituição em duas partes distintas. Ele dizia que os arranjos das importantes repartições do Reino Unido tinham produzido um "verdadeiro monstro de duas cabeças", sendo impossível que os interesses comerciais de tal reino pudessem ser regulados por duas Juntas de Comércio. Hipólito da Costa certamente se preocupava com os rumos das políticas implementadas no Rio de Janeiro, sobretudo com as irrestritas importações de tecidos finos no Brasil, o que não era compatível com a proteção do mercado interno do Reino Unido. Reprovando tais políticas, o correspondente sentenciava: "De uma coisa podem esses ministros estar seguros, é que os portugueses não hão de satisfazer só com o nome de união; e que se faltar à realidade, uma vez que declaram a nomenclatura, o erro do presente modo de administração será tão conspícuo, que ninguém lhe perdoará as más conseqüências" ${ }^{\prime 40}$.

Assim, estabelecia-se o conflito de difícil solução, uma vez que os interesses das elites mercantis de ambos os lados do Atlântico, ainda que às vezes tivessem objetivos comuns, a exemplo do fim do comércio ambulante, eram, do ponto de vista da organização política do Império, irreconciliáveis. As distinções dos usos e costumes nas praças portuguesas e brasileiras eram principalmente pretextos para uma disputa política e econômica que os portugueses viam escapar-lhes pelos dedos. Por isso, não estavam dispostos a fazer concessões. Como bem dizia Hipólito da Costa: os portugueses não se satisfaziam apenas com a denominação de "União", principalmente se não estivessem à frente dela.

Todo esse processo só termina em Portugal no ano de 1826, quando a Corte portuguesa já havia retornado ao continente europeu e as decisóes tomadas no Brasil recém-independente já não submetiam a Junta de Comércio portuguesa. Uma resolução, publicada na Gazeta de Lisboa, n.177, em 1826, era uma tentativa de conciliar o interesse de todas as partes envolvidas na querela que se arrastou por tantos anos. D. João reconhecia a importância da manutenção das classes estabelecidas, mas delimitava espaço de atuação para ambulantes, de ambos os sexos, e para alfaiates e modistas que concorriam com os mercadores. A aparente incompatibilidade desses grupos acabou encontrando uma forma de acomodação na 
nova resolução. Finalmente, ela assegurava um espaço de mercado para cada grupo, demonstrando que a intervenção política era a melhor solução para a conciliação. O problema havia se tornado bem fácil de resolver, dizia respeito somente ao estado português e não mais ao Império.

\section{Notas}

${ }^{1} \mathrm{O}$ autor enfatiza o uso do termo "vassalo" em detrimento do termo "súdito" em função do caráter de relaçóes de poder pactuado que revela o primeiro termo. (GUERRA: 2003: 40)

${ }^{2}$ Valentim Alexandre (1993) define como a "opção americana" a vertente do grupo político mais influente, às vésperas da invasão francesa, liderado por D. Rodrigo de Sousa Coutinho e que tinha por objetivo a transferência da corte real para a América com o auxílio dos ingleses.

${ }^{3}$ Domingos Vandelli : "Memória sobre um Plano de Regimento para a Real Junta do Comércio, Agricultura, Fábricas e Navegação deste Reino e Seus Domínios". Biblioteca Nacional da Ajuda, códice 54-V-14.

${ }^{4}$ Ver: MADUREIRA (1997:50). O autor descreve a composição da Nova Junta e seus cargos analisando o equilíbrio entre magistrados e negociantes.

${ }^{5}$ Citado por Nuno Madureira (1997:52).

${ }^{6}$ Jorge Pedreira. Os Homens de Negócio da praça de Lisboa de Pombal ao vintismo. Lisboa: Universidade Nova de Lisboa, 1995 (Tese).p.70.

${ }^{7}$ Ver: Geraldo BEAUCLAIR. Raizes da indístria no Brasil. Rio de Janeiro: Studio F\&S Editora, 1992. pág. 51-52. Segundo esse autor, o procedimento da Junta era o seguinte: o interessado dirigia seu requerimento ao Monarca, e era então encaminhado ao tribunal por portaria da Secretaria de Estado dos Negócios do Reino, sendo determinado que o Deputado-Inspetor emitisse parecer sobre o pedido. Estudado o caso, o parecer emitido pelo Inspetor era base para a decisão final dos membros da Junta. Para concluir o trâmite, o Monarca mandava colocar uma nota de acordo na primeira página de consulta. Aprovado o benefício, fazia-se a Provisão, que era o documento legal enviado ao requerente.

${ }^{8}$ Arquivo Nacional. Biblioteca: MENDONÇA, Marcos Carneiro de (transcrição e reprodução fac-similar). "Aula do Commercio. Edição comemorativa do bicentenário da morte de Sebastião José de Carvalho e Mello, Marquês de Pombal (1782-1982)". Rio de Janeiro: Xerox do Brasil, 1982. ARQ 1151.

${ }^{9}$ Refiro-me aqui às cinco classes de mercadores estabelecidas em Portugal, e à determinação dos espaços públicos que deveriam ser ocupados por cada uma dessas classes. São elas: Mercadores de lã e seda (Rua Nova dos Ferros, Conceição Velha e Rua dos Escudeiros); mercadores de lençaria (chamados da Fancaria); mercadores de meias de seda (chamados da Capela); marcadores de meias de lá (chamados de Casa da Misericórdia, Arco do Rocio, e Campainha); mercadores das lojas de retrós (Rua Nova e Rua dos Escudei- 
ros). As aposentadorias definiam a permanência de um mercador em um determinado imóvel, de acordo com o arruamento.

${ }^{10}$ Correio Braziliense de 1812, Seção de periódicos microfilmados da Biblioteca Nacional de Lisboa. Rolo 1728, p. 691-3.

${ }^{11}$ Nastro eram fitas estreitas de linho, seda ou de outro material, feitas para atar ou trançar os cabelos das mulheres.

${ }^{12} \mathrm{O}$ Estatuto das Cinco Classes de Mercadores foi criado no ano de 1757. Uma transcrição deste documento pode ser vista em: MENDONÇA, Marcos Carneiro de .Op cit.

${ }^{13}$ Arquivo Nacional da Torre do Tombo, ANTT, Junta do Comércio, livro 139, fls. $95-$ 6.

${ }^{14}$ ANTT, Junta do Comércio, mç. 349, cx 711. Essa representação conta com 32 assinaturas e é datada de 11 de maio de 1813 . Ela foi elaborada para fazer frente a uma representação semelhante feita pelos mercadores das cinco classes que, no ano anterior, haviam apresentado um abaixo-assinado feito por negociantes britânicos que garantiam preferir vender seus produtos para mercadores estabelecidos do que vendê-los para comerciantes ambulantes. ANTT, Junta do Comércio, mç. 367, cx. 738.

${ }^{15}$ Idem. Documento datado de março de 1813.

${ }^{16}$ Nem mesmo a Lei de 1802 que estabelecia que todos os donos de manufaturas poderiam abrir lojas, quando essas não prejudicassem o comércio já estabelecido. ANTT, Junta do Comércio, Livro 133, fl.224.

${ }^{17}$ Idem. Documentos anexos ao mesmo processo.

${ }^{18}$ Documento da Junta de Comércio localizado no Arquivo Histórico das Obras Públicas de Portugal. JC/10.

${ }^{19}$ ANTT, Junta do Comércio, mç. 367, cx. 738.

${ }^{20}$ ANTT, Junta do Comércio, mç. 367, cx. 738. Referem-se ao Livro 5, Tomo $60 \$ 6$ das Ordenações do Reino.

${ }^{21}$ ANTT, Junta do Comércio, mç. 367, cx. 738.

${ }^{22}$ Arquivo Histórico das Obras Públicas: L.2, fl 44v-47. Lisboa, Portugal.

${ }^{23}$ ANTT, Junta do Comércio: Mç 349 cx 711.

${ }^{24}$ Uma representação dos mercadores das cinco classes de Portugal datada de 1824 ilustra bem todo o sentimento da classe em relação aos seus concorrentes: "um aluvião de indivíduos de ambos os sexos, deixando as aldeias e campos em que nasceram, e os trabalhos rústicos e domésticos em que foram criados, em que são precisos, vem intrometer-se em traficar nos gêneros privativos dos suplicantes, (...) os mercadores, os quais estão vendo vencer-se as Letras, as rendas das lojas e os ordenados de seus caixeiros sem poderem acudir estes precisos pagamentos, porque nas suas lojas só entram mendigos, em lugar dos antigos compradores que as freqüentavam (...) [eles] se aplicaram desde seus mais tenros anos à profissão mercantil, fiados na promessa e proteção das leis que regularam e classificaram o comércio mercantil, com exclusão de todo indivíduo para ele não habilitado pelo meio e forma legal (...). Lisboa, outubro de 1824". ANTT, Junta do Comércio, mç. 367, cx. 738 . 
${ }^{25}$ Junta do Comércio - ANTT. Mç 367 cx 738.

${ }^{26}$ Junta do Comércio - ANTT; Mç 367 cx 738.

${ }^{27}$ Carta publicada nos Anais da Biblioteca Nacional, 1910. p. 505.

${ }^{28}$ Esse autor, que viveu entre, 1657 e 1716, produziu outra obra referencial sobre a arte do comércio: Le Parfait négociant ou instruction générale pour ce qui regarde lê commerce de toute sorte de marchandises tant de France que dês pays étrangers. Paris, 1675.

${ }^{29}$ Junta do Comércio, Agricultura, Navegação e Fábricas. Cx 379 do Arquivo Nacional. ${ }^{30}$ Junta do Comércio, Agricultura, Navegação e Fábricas. Cx 379 do Arquivo Nacional. ${ }^{31}$ Junta do Comércio, Agricultura, Navegação e Fábricas. Cx 379 do Arquivo Nacional. 32 Junta do Comércio, Agricultura, Navegação e Fábricas. Cx 379 do Arquivo Nacional. ${ }^{33}$ Junta do Comércio, Agricultura, Navegação e Fábricas. Cx 379 do Arquivo Nacional. Eles se referem à Pragmática de 24 de março de 1749, capítulo 18; ao Alvará de 19 de novembro de 1757 e ao Alvará de 21 de abril de 1751.

${ }^{34}$ Junta do Comércio, Agricultura, Navegação e Fábricas. Cx 379 do Arquivo Nacional. ${ }^{35}$ Refere-se aqui à pretensão dos varejistas brasileiros de serem divididos e manterem estatutos conforme as cinco classes de mercadores estabelecidas em Portugal desde o ano de 1757, durante a administração pombalina, as quais nunca existiram no Brasil.

${ }^{36}$ Junta do Comércio, Agricultura, Navegação e Fábricas. Códice 46, vol. 4, fls. 149-151 do Arquivo Nacional.

37 Idem.

${ }^{38}$ Jorge Pedreira, Op. Cit. p.80.

${ }^{39}$ Ver: Dictionnaire universel du commerce, d'histoire naturelle et des arts et métieres por Jacques Savary dês Bruslons. Verbetes: Mercador e Commercio.

${ }^{40}$ Biblioteca Nacional de Lisboa, Seção de periódicos microfilmados, Correio Braziliense, 31 de agosto de 1816, rolo 1735, fls. 294-6.

\section{Referências bibliográficas}

ALEXANDRE, Valentim. Os sentidos do Império. Porto: Afrontamentos, 1993. BEAUCLAIR, Geraldo. Raizes da indústria no Brasil. Rio de Janeiro: Studio F\&S Editora, 1992.

GUERRA, François-Xavier. "A nação moderna: nova legitimidade e velhas identidades”. In: JANCSÓ, Istvan. Brasil: Formação do Estado e da Nação. São Paulo: Hucitec/Fapesp, 2003.

. \& ANNINO, Antonio. Inventando la Nación: Iberoamérica siglo XIX. México Fondo de Cultura Económica, 2003.

HESPANHA, António Manuel. "A constituição do Império português. Revisão de alguns enviesamentos correntes". In: FRAGOSO, João, BICALHO, Maria Fernanda \& GOUVÊA, Maria de Fátima (orgs.). O Antigo Regime nos Trópicos: 
a dinâmica imperial portuguesa (séculos XVI-XVIII). Rio de Janeiro: Civilização Brasileira, 2001.

. Ass Vésperas do Leviathan: Instituiçôes e poder politico, Portugal século XVII. Coimbra: Livraria Almedina, 1994.

MADUREIRA, Nuno Luís. Mercado e privilégios: a indústria portuguesa entre 1750-1834. Lisboa: Estampa, 1997.

MENDONÇA, Marcos Carneiro de (transcrição e reprodução fac-similar). "Aula do Commercio. Edição comemorativa do bicentenário da morte de Sebastião José de Carvalho e Mello, Marques de Pombal (1782-1982)". Rio de Janeiro: Xerox do Brasil, 1982.

PEDREIRA, Jorge. Os Homens de Negócio da praça de Lisboa de Pombal ao vintismo. Lisboa: Universidade Nova de Lisboa, 1995 (Tese).

SALES, Alberto Jaqueri de. Dicionario Universal de Commercio. Trad. e adaptação manuscrita do Dictionnaire Universel de Commerce, de Jaques Savary des Brulons, 4 vols. 1813. (Seção de Reservados da Biblioteca Nacional em Lisboa).

WEBER, Max. A ética protestante e o espirito do capitalismo. São Paulo: Pioneira, 1989.

\section{Resumo}

Este artigo trata do conflito de interesses entre mercadores portugueses - homens e mulheres - em torno da criação e transferência de poderes para a Junta de Comércio, Agricultura, Fábricas e Navegação do Estado do Brasil e Domínios Ultramarinos como fórum de decisão dos problemas internos de mercado em Portugal. Essa transferência cria uma inusitada relação de dependência das praças de comércio da Metrópole em relação à antiga colônia americana, promovida a Reino Unido de Brasil, Portugal e Algarves.

Palavras-chave: Império Luso-Brasileiro, conflito, comércio varejista, mercadores.

\section{Abstract}

This article studies the conflict of interests among Portuguese merchants - men and women - because of the creation of the Junta de Comércio, Agricultura, Fábricas e Navegaça of of the State of Brazil and Foreign Domains as main forum for decisions about specific problems of market in Portugal. This change created an unusual relationship of dependence of the Metropolitan trade from the old American colony, who was promoted to United Kingdom of Brazil, Portugal and Algarves.

Key words: Luso-Brazilian Empire, conflict, retail trade, merchants. 